\title{
Political Godfather-Son Conflict in South-Western Nigeria, 2004-2006: The Role of the Press
}

\author{
Muyiwa Popoola* \\ Department of Communication and Media Studies, Ajayi Crowther University, Oyo State, Nigeria \\ *Corresponding author: Muyiwa Popoola, Department of Communication and Media Studies, Ajayi Crowther University, Oyo State, Nigeria, Tel: +234-802-313-8; \\ E-mail: whereispopson@gmail.com \\ Rec date: Feb 02, 2014, Acc date: Jul 02, 2014, Pub date: Jul 09, 2014 \\ Copyright: ( 2014 Popoola M. This is an open-access article distributed under the terms of the Creative Commons Attribution License, which permits unrestricted use, \\ distribution, and reproduction in any medium, provided the original author and source are credited.
}

\begin{abstract}
Political godfather-son conflict has been upsetting Nigeria's development. The conflict, rooted in clash of values, interest, needs and resources, involved political office holders in top hierarchy of government. There have been scholarly works on the gate-keeping and agenda setting role of the media in political conflicts, but the actual role the Nigerian media play in political godfather-son conflict is inadequate in literature. Thus, this study was carried out to determine how selected newspapers reported such conflict between a former State Governor, Rasheed Ladoja and a political godfather Lamidi Adedibu, in Oyo State, South Western Nigeria. The study period was 2004 to 2006 when the conflict heightened and escalated to physical violence and civil unrest. Five nationally-circulated newspapers were selected for the study, namely: Daily Champion, Daily Trust, Nigerian Tribune, The Guardian and The Punch. Purposive sampling was used to select 105 editorial items in 90 editions of the selected newspapers. The study adopted dialectical hermeneutics in data gathering and analysis. This was done to investigate partisanship, fairness, bias and largely the extent of social responsibility displayed in reporting the conflict by the newspapers. It was discovered that the vast reportage of the conflicts was largely negative as the newspapers overwhelmingly published stories that contributed to escalation of the conflicts. The reportage reflected incitement, partisanship and bias on the part of the newspapers. The reportage could not have helped in reconciling the conflicting parties, but fuelled the conflicts to violence and public unrest. The reportage was socially irresponsible and unethical journalistic practice has become a constraint to the development of democracy in Nigeria. The Nigerian press need to be development oriented by practising peace journalism. This will advance Nigeria's democracy, as well as help prevent any military intervention in Nigeria's politics in the future.
\end{abstract}

Keywords: Political godfather-son conflict; Reportage; Newspaper; Nigerian press; Violence

\section{Introduction and Statement of Problem}

A review of scholarly works and research findings with respect to accuracy of reporting of conflict by the mass media shows that it may be fallacious sometimes to say that the media always handle conflict reporting with fairness, accuracy and justice, at least as expected of a socially responsible media. Frankly, if the allegations of distortion of contents and biased reporting as well as inaccuracy in reporting, put up against the media appear not to have been substantiated considerably in other conflict situations, there are seemingly scholarship evidences supporting the allegations as far as political conflict reporting by the mass media is concerned. This observed role of the media negates the canons of a socially responsible and development-oriented press in democratic societies, as contained in the works of Siebert, Peterson and Schramm [1] and Mc Quail [2-4]. Consequently, seeming indictment of the media in political conflict situation is worth investigating in Nigeria. Since 1960 when the country attained independence, there have been occurrences of political conflicts which have thwarted the country's political development. Thus, this study was carried out to investigate and determine how the Nigerian press reported a particular tumultuous and ruinous type of political conflict recognized and named as political godfather-son conflict. This conflict has been a persistent problem of
Nigeria's democracy as it has generated and led to many political conflicts with attendant violence in Nigeria.

Political godfather-son conflict arises from disagreement and clash between or among political associates and acquaintances. The face-off is most often due to personal differences in respect of needs, value, interest and resources. In the current political dispensation in Nigeria, there have been instances of how some individual politicians (often rich and influential), who had sponsored and possibly bankrolled candidates or contributed immensely to the electoral victory of candidates, engage in crises with their candidates as soon as such candidates win elections, because they (the benefactors) perhaps want to dictate governance to their beneficiaries This conflict has its antecedents in what Joseph [5] brands as prebendalism. Perhaps drawing his insight from the Catholic Encyclopedia which conceptualizes a prebend as the "right of a member of chapter to his share in the revenues of a cathedral", Joseph describes and explains state offices as prebends that can be appropriated by officeholders, who use them to generate material benefits for themselves and their constituents and kin groups. He uses the term to describe the sense of entitlement that many people in Nigeria feel they have to the revenues of the Nigerian state. He captures this scenario more aptly:

Democratic politics and prebendal politics are two sides of the same coin in Nigeria; each can be turned over to reveal the other... The system of prebendal politics enables divergent groups and constituencies to seek to accommodate their interests... The system is often wasteful, unproductive... It contributes to the increasing 
affluence of the relative few, paltry gains for a large number and misery for the great majority of people. Since it is a self-justifying system which grants legitimacy to a pattern of persistent conflict, and since its modus operandi is to publicize ethnic, religious and linguistic differences, it serves to make the Nigerian polity a simmering cauldron of irresolvable tension over which lid must regularly be clamped and just as regularly removed.

Consequently, the extent of the grip of prebendalism on Nigeria's political life is such that it prevents the nation from being able to practice democracy perfectly. Since Nigeria's independence, several political godfather-son conflicts have occurred in the country. The influence wielded by individuals, identified and recognized as political godfathers, seems total and daunting. Adeoye [6] captures political godfatherism in Nigeria and declares, inter alia, that:

... Godfathers have in the most brazen manner hijacked the political machinery at all levels. It means then that what is called election in Nigeria is nothing but the expression of the narrowly defined will of a few dishonest individuals who feel that they have the power to manipulate the entire electoral process in favour of their anointed godsons.

According to Okoye [7], the godfatherism phenomenon in the electoral process results from the commoditization of state power, and the struggle to acquire it by the dominant political class. Using Nigeria as a reference, Okoye observes that the non-recognition of independent electoral candidates has made political parties a rare commodity to be bargained for by political aspirants. In his words, "those of them that are desperate to capture political offices they crave for, are often amenable to the conditionalties of those who possess the wherewithal to enable them achieve their political aspirations." Close to that is Olarinmoye's [8] commentary on political godfatherism, in which he describes the phenomenon as politics of sponsorship to political positions, control of political power, political patronage and the ultimate control of state treasury, personnel and resources. He exposes the characters of political godfathers by identifying them as men who have the power personally to determine both who gets nominated to contest elections and who wins in same elections. Based on the practice of political godfatherism therefore, it follows that there would be peace, unity and tranquility at any time that there is harmony of interests among political players even at the expense of the governed. However, when there is disharmony as a result of needs, value, interest and resources, in political circles, what follows is political godfather-son conflict that may take several dimensions. In Nigeria, there have been occurrences of these conflicts which have plagued the country's democracy because of the prominence and the positions of the conflicting parties in government.

There have been scholarly works on the gate-keeping and agenda setting role of the media in political conflicts, but the actual role the Nigerian media play in political godfather-son conflict is inadequate in extant literature, as empirical studies in this regard seem unclear and scholarly non-provocative. Thus, there has been a wide gap in knowledge on the actual role of the media in political conflict situations, especially as it concerns this type of political conflicts in Nigeria and emerging democracies. Hence, this study was carried out to fill that gap by determining how selected newspapers reported such conflict between a former governor of Oyo State, Rasheed Adewolu Ladoja and Chief Lamidi Adedibu, a political godfather and chieftain of People's Democratic Party (PDP) in the State. The conflict happened in the fourth republic which started in 1999 but escalated to civil unrest, public violence and destruction of lives and properties between 2004 and 2006 .

\section{Research Questions}

Based on the articulated problem of this study, the following research questions were put forward to serve as guide for the study:

- To what extent did the reportage tend to escalate and de-escalate the conflicts within the period under study?

- To what extent did ownership of the selected newspapers affect the reportage of the conflicts?

- How socially responsible was the coverage of the conflicts by the selected newspapers?

\section{Scholarly Works on Media and Political Conflicts in Nigeria}

Isola [8] searched the literature in respect of the role of the media in political conflicts in Nigeria, and discovered that the earliest studies within the continuum of media and political communication in Nigeria are those of Omu. In his first scholarly work entitled Press and Politics in Nigeria, Omu explores the role of newspaper as an organ of the press in the pre-colonial, colonial and post- colonial politics in Nigeria. That work and subsequent ones provide valuable insights into the contributions of newspaper to the political development as well as the political pitfalls of the Nigeria nation. This study draws immensely from those insights to present a fresh insight into understanding the role of the press in personality-induced political conflicts in Nigeria. Also in his work entitled: House of War, Babarinsa [9] chronicles the bitter power struggles that culminated in the various political conflicts that plagued Nigeria right from pre-independence to the First and Second Republics. Through careful and meticulous observation, Babarinsa captures historically some of the intrigues, political backstabbing and shameful conducts of the local media which led to the massive killings and destructions that followed the personalityinduced political conflicts in some states in the South-Western part of Nigeria [10]. As an empirical study, Akinsanya carried out a content analysis of selected newspapers in Nigeria to ascertain their reportage of the 1979 elections. He discovered that most of the selected newspapers, except a few with little or no political affiliation, did not exhibit neutrality in the coverage of the elections. Many of the newspapers whose contents were analyzed favoured one or the other of the existing political parties, a discovery that runs contrary to the principle and tenets of a socially responsible press.

Also, Adebanwi [11] explores the role of the print media in contestations for political power and in carving distinct identities for the ethnic nationalities that constitute the Nigeria nation state. $\mathrm{He}$ examines how words are deployed and mobilized in the press to nourish and sustain power relations among the ethnic nationalities and in deflecting power domination by the various dominant ethnic groups in Nigeria. He concludes that any efforts directed at integrating Nigeria will be a myth until the smaller nations within the entity of the traditional states, are ready to surrender some of their political identities towards building a cohesive Nigeria.

Adebanwi's approach confers importance on textual analysis, which is the supplementary research method adopted in this study. Textual analysis proves valuable in unearthing and ascribing meanings to the contents of newspapers selected for this study. Literature is also replete with other related works which are of immense benefit to this study. 
The works of Anifowose; Faleti; Popoola; and Isola [8], among others, also address the problem of this study in some respects. These works expose the various cycles of violence that have accompanied elections in Nigeria; examine the myths propagated in the media about the conduct of violence- free elections in the country; explore historical events that often emerge in the processes leading to election; and recommend ways by which the media could exhibit responsibility as the Fourth Estate of the Realm.

However, all these related works seem to have focused on elections, electoral violence and the role played by the media in the escalation and de-escalation of the violent acts that accompany elections in Nigeria. It appears that there have not been any remarkable and substantial works on the reportage of political godfather-son conflicts in Nigeria. Irrefutably, such conflicts appear strong enough as catalysts for other political conflicts and their attendant violent acts. Consequently, by focusing on the reportage of political godfather-son conflict in the South Western Nigeria, this study will come up with useful recommendations on how such conflicts can be reported by the media, with a view to achieving a peaceful political process.

\section{Scope of the Study}

The focus of this study was the newspaper reportage of political godfather-son conflict between ladoja and Adedibu in the South Western geopolitical zone in Nigeria within a period of 2004 and 2006 when the conflict heightened. Consequently, the study concentrated on how selected national newspapers reported the conflict. Five national newspapers were selected for the study, and they included: Daily Champion, Daily Trust, Nigeria Tribune, The Guardian and The Punch. The selection of these newspapers was also based on some factors. First, it is logical to assume that any conflict involving individuals at the top hierarchy of government in federalism, such as Nigeria's, would have implications for national development. Hence, newspapers to be chosen in this respect have to be national in their spread and circulation. This is the first rationale behind the choice of the newspapers which are rated as national newspapers by the Audit Bureau of Circulation (ABC), Nigeria Union of Journalists (NUJ), Nigeria Guild of Editors (NGE) and Nigeria Press Council (NPC). Also, the ownership identity of the founders of the newspapers was another factor that prompted the choice of the newspapers. This was to ascertain if there was any relationship between ownership of each of the newspapers and the slant of the reportage of the conflicts.

The study was however fraught with a number of limitations. One is that it was not possible to sample all the editions of the selected newspapers regarding their reportage of the conflict, owing to the reason that the data to be gathered would be too enormous to manage and discuss if all the editions were included in the sample. Also, if all the editions of the newspapers were sampled, there were possibilities that some editions might not carry stories and journalistic genres to be analysed. Thus, a sample of editions that carried editorial and journalistic items needed for analysis had to be drawn for the study. This was done not only to make the data manageable, but ensure that only editions that carried stories on the conflicts were sampled.

\section{Methodology}

The study used the dialectical hermeneutics style of textual analysis in data gathering and analysis. This method was adopted for the study because it is used by cultural studies researchers to interpret textual matters with a view to bringing out possible intentions of the writers of such text. This method was suitable for this study as it made it practically possible to interpret the intentions, opinions and dispositions of the selected newspapers. Thus, subjective analysis was pivotal to the study especially for bringing out actually the escalatory and de-escalatory nature of the reportage; and also investigating partisanship, bias and neutrality on the part of the newspapers. To a large extent, the method was used to measure the extent of social responsibility displayed by the newspapers in reporting the conflicts.

\section{Sample and sampling procedure}

The sample size for this study was 90 editions of the five newspapers. Breaking this down, 18 editions of each newspaper were sampled in respect of the conflict. Systematic and purposive methods were adopted in the sampling of the editions of each of the newspapers per year for the three year frame (2004-2006). Thus, for the conflict, from a segment of two months, starting from 2004 to 2006, at least one edition of each of the newspapers was sampled, and as such there were at least 6 editions of each newspaper per year, and at least 18 editions of each newspaper for the three-year frame. However, in order to ensure that sampled editions were editions that carried stories on the conflict, purposive sampling was used to select editions of the newspapers that carried mainly stories on the conflict with manifest or implicit inciting contents. This was done to investigate partisanship and neutrality as reflected in the newspapers in reporting the conflict and its accompanying violence.

\section{Method of data presentation and analysis}

As stated earlier dialectical hermeneutics style of textual analysis was used for the study. Consequently, in order to generate relevant data through the use of the method, two broad content categories were devised. Subsequently, these content categories were developed in order to determine and analyze the reportage of the conflicts by the selected newspapers. The two principal content categories were:

Conflict escalatory stories: These were stories that fuelled the conflicts. Such stories increased the intensity of the conflicts and led to manifestation of the conflicts in forms of violence, destruction of lives and property and anarchy. Such stories were operationalised as:

- Favourable and unfavourable stories: These were stories which contained the perspective of only one of the two conflicting parties at the expense of the other party. Such stories did not report the angle of the other party. These were stories which were slanted in support of a conflicting party and which were unfavourable to the other conflicting party.

Conflict de-escalatory stories: These were stories that exhibited the canons of socially-responsible journalism and peace journalism. The stories tended to reconcile two conflicting parties by mentioning the two perspectives and emphasizing efforts aimed at resolving the conflicts and the need for resolution of the conflicts in order to bring about peace. Such stories were operationalised as:

- Resolution stories: These were stories in which the two sides of the two conflicting parties were mentioned. In such stories, efforts aimed at resolving the conflicts were reported.

The data obtained from the use of dialectical hermeneutics were thoroughly explored and analyzed to extract relevant information that are related to identified elements of the study. Both the implicit and manifest contents of the sampled newspapers were subjected to discursive and narrative analysis. The focus of analysis in the sampled 
newspapers was mainly political stories with manifest or implicit inciting contents. This was done to measure the extent of social responsibility displayed by the newspapers in reporting the conflicts.

\section{Findings}

Discussion in this section is aimed at providing answers to the specific research questions raised in this study. This is done through the application of the relevant data obtained through instruments used for this study.

\section{Research Questions 1, 2 and 3}

\section{Research question 1}

To what extent did the reportage tend to escalate and de-escalate the conflicts within the period under study?

\section{Research question 2}

To what extent did ownership of the selected newspapers affect the reportage of the conflicts?

\section{Research question 3}

How socially responsible was the coverage of the conflicts by the selected newspapers?

These questions sought to bring out the escalatory and deescalatory nature of the stories carried by the newspapers. The questions also sought to determine the manifest or implicit inciting contents of the newspapers with a view to investigating partisanship and neutrality as reflected in the newspapers in reporting the conflict and violence that accompanied it. Also, the questions sought to ascertain how adherent the selected newspapers were to the tenets of socially-responsible media by being fair, non-partisan and reconciliatory in reporting conflicts. The data that provides answers to these questions are hereby presented and analyzed qualitatively using the dialectical hermeneutics style of textual analysis. However, in order to make the data manageable and sizeable, a few of the contents of the sampled editions of the newspapers regarding the conflict are analyzed thus:

\section{Ladoja and Adedibu Conflict}

\section{Newspaper}

Daily Champion - In the heat of the conflict, Daily Champion published the negative exchanges between the conflicting sides in form of features and hard news. The newspaper ignored its expected role of being socially responsible. It published outbursts from Adedibu and Ladoja for public consumption, ignoring the potential consequences of such reportage. This is demonstrated below:

Adedibu Vs Ladoja: The intrigues, power play: The political intrigues and power play between the Oyo State Governor Rashidi Ladoja and his estranged political godfather, Alhaji Lamidi Ariyibi Adedibu took centre stage in the nation's political scene last week...... Adedibu was so much carried away by Ladoja's loyalty and submissiveness, that he told newsmen last week that 'when Ladoja was looking for the governorship, if I ask him to open his mouth and eat my faeces, he would gladly and quickly do it without hesitating'. It is now an open secret that Ladoja is not a yes-man, he only stooped to conquer. He took the bow, to get what he wanted and he got it. Soon after he became governor, Ladoja showed his true colour. He stopped the regular pilgrimage to Adedibu's Molete, Ibadan residence......

In the same story and in response to Adedibu's statement, Ladoja's outburst was presented thus:

During the state PDP congress last Thursday where Adedibu and Adeojo were expelled, Ladoja openly declared that Adedibu wanted him to run the government in his (Adedibu's) sitting room.

'The only question I faced was, will Adedibu allow Ladoja to work? $\mathrm{He}$ (Adedibu) thought he can dictate to me. He thought I am a kid, but I disappointed him. This Ladoja is not a kid but a father and a grandfather. I have a mind of my own..... (July 28, 2004, page 39)

This reportage fuelled the conflicting situation and subsequently midwived the birth of other stories that created confusion, helplessness, and ultimately, political disrepair in Oyo State like the below:

Ladoja: In the midst of storms: For the governor of Oyo State, Senator Rashidi Ladoja, this is not the best of times. The governor is currently facing the battles of his life left, right and centre. Governor Ladoja is not only facing the political battle as manifested in his deeprooted controversy with his political godfather and strongman of Ibadan politics, Alhaji Lamidi Ariyibi Adedibu.....But the recurring question among conscientious members of the society has been why and how did Governor Ladoja find himself trapped in this messy situation? ... Who next, is the question? Would the latest plea by President Olusegun Obasanjo to the parties in the protracted crisis finally resolve the political imbroglio? Time will definitely tell..... (December 29, 2005, Page 38)

Some days later, Adedibu's claim that Ladoja was planning for a state of emergency was carried by the newspaper and it was published thus:

Oyo: Ladoja wants state of emergency... Adedibu claims: Embattled governor of Oyo State, Senator Rashidi Ladoja is routing for the imposition of state of emergency rather than being forced out of the office through impeachment, his estranged political godfather and strongman of Ibadan politics has claimed. Speaking with newsmen at his Molete residence in Oyo State yesterday, Alhaji Adedibu stated that "Ladoja had based his calculation on the false belief that when an emergency rule is imposed, it would be an encompassing one, which would unseat all elected public officers in the state including the lawmakers.....(January 7,2006, Page 6)

Adedibu called a press conference to heighten public anxiety and arouse the emotion of those in the state as a measure to defame the person of Ladoja. The general picture of insecurity painted in the papers obviously generated panic among the public and made the residents to see Ladoja as a threat to security. This drew a reaction from the newspaper as it came out with an opinion article portraying Ladoja as a weakling and not fit to govern the state. Therefore, the paper, did not fail to repeat and impress it upon the public that Ladoja was swimming in so many problems and has therefore lost concentration in directing the ship that conveys Oyo State. It found expression in the below:

Ladoja: Too damaged to govern Oyo state: ...Before you begin to fault Adedibu for meddling in the affairs of the State, you ought to understand that Adedibu did not just appear from thin air.... Ladoja 
cannot say without equivocation that he did not know how he was (s)elected as governor... Had Ladoja not spent fortunes to get himself elected, he might not have found himself in this dire strait because he would have owed nothing to Adedibu. And if he found himself in these troubles, he would have resigned honorably... (January 12, 2006, Pg 13)

The process of causing panic eventually climaxed into Ladoja's removal by Adedibu having made good his threat previously to do so. Stories churned out by Daily Champion sought to attack the reputation of Ladoja and praise Adedibu's efforts through statements attributed to those in power. This could have escalated the situation to the extent that the supporters of the two sides would clash and break down peace and order in the state.

Oyo: Rumpus over ladoja's removal: ..Some political watchers have in fact accused Ladoja of being politically naïve hence he got what he deserved. The argument is that if ex-governor Ladoja had handled Adedibu well, the fate that befell him would have been averted. This argument is however neither here nor there but the fact remains that past and present politicians in Oyo State who ignored or try to rubbish Adedibu had ended up either being annihilated or humiliated. Even while he held sway as the executive governor, Adedibu continued to tell Ladoja to his face that he (Ladoja) was hitherto a nonentity, politically until the grandmaster and kingmaker picked him up dusted him and made him first of all a Senator during the ill-fated third republic.......President Olusegun Obasanjo recently commended Adedibu's political clout and sagacity. Obasanjo, we gathered may have instructed Adedibu to "deal with Ladoja", following what was termed as the President's disappointment over Ladoja and how he was handling the Oyo crisis. (February 4, 2006, Page 10)

In the midst of the confusion that followed, the blatant abuses had turned into a full blown crisis involving the factions of the conflicting sides unleashing violence in the state. Consequently, the entire Oyo State was became tensed and a beehive of destruction of life and property as reported below:

Ladoja, adedibu's men in gun battle: Barely 48 hours after Peoples Democratic Party (PDP) brokered peace parley ended in Oyo State, camps of impeached governor, Senator Rashidi Ladoja and his estranged godfather, Alhaji Lamidi Adedibu clashed again.The clash which saw both faction firing several gunshots and freely using dangerous weapons occurred at the Ibadan North-West local government council, Onireke, Ibadan... It was further gathered that when loyalists of Adedibu left the Ibadan North-West secretariat, they allegedly took away the mace of the council, money and the kits already printed with Alao-Akala's picture which the councilors wanted to use for the rally at Oyo today...(June 8, 2006, front $\mathrm{pg}$ )

This saw Ladoja going to court to appeal the ruling and he won, then Daily Champion came forward with an editorial to present the issue thus:

Ladoja's victory: When 18 out of the 32 members of the Oyo State House of Assembly came together and in a bizarre manner contrived the "impeachment" of Governor Rashidi Ladoja, all true democrats in the country and beyond knew that a dirty slap had been landed on the face of democracy.All who knew anything about due process knew that the clear case of illegality could not stand when tested in the law courts. A few were afraid that the judiciary may buckle under the weight of pressures from those behind the purported impeachment, notably, the self-styled strongman of Ibadan politics, Alhaji Lamidi Adedibu. In the face of deployment of brutal force against the hapless government of Governor Ladoja, many thought the governor would run and not look back, many thought he would surrender his mandate without a fight..... Those who sponsored or participated in the illegal impeachment should have learnt their lessons and must bury the hatchet and co-operate fully with Ladoja so that the state can move forward and so that every threat to the nation's nascent democracy can be nipped in the bud. (December 18, 2006, Editorial)

Shortly after the court ruled in favor of Ladoja, the editorial which is supposed to be an impartial opinion of the paper published was biased and was not balanced. The resentful tone for the Adedibu faction could have further escalated the situation, though Daily Champion could be said to be right in condemning the illegal impeachment, however, it was not detached from the issue as the editorial bespeaks sentiments that are bias in nature.

Ladoja gets free impeachment notice: Prospect of another intriguing political drama in Oyo State played out yesterday as 19 members of the state assembly, loyal to Chief Lamidi Adedibu, served a fresh notice of impeachment on the state governor, Chief Rashidi Ladoja. The move is coming less than two months after the reinstatement of the governor via Supreme Court ruling which upheld the Court of Appeal judgment that quashed his impeachment on December 12, 2005 by the same lawmakers...(February 2, 2007, Front Page).

One would have thought the Pro-Adedibu lawmakers would let sleeping dogs lie and would desist from fomenting trouble. But, this was not the case as barely some months after Ladoja's impeachment, he was served a fresh notice and it was presented in a way that set the ground for another conflicting drama between the two conflicting sides.

2007: Let's do away with Adedibu: Oyo State Governor, Rashidi Ladoja, has called on the people of the State to be mindful of the statement of President Olusegun Obasanjo that the People's Democratic Party (PDP) chieftain, Alhaji Lamidi Adedibu, could not be reformed and therefore should be managed saying, if the man is so used to violence and corruption that he could not be reformed as claimed by Mr. President, then we don't need him in our quest for true democracy and he should be done away with' (March 17, 2007,pg 7)

Successively, the 2007 elections were drawing closer. The newspaper published Ladoja's appeal to the people of the State to do away with Adedibu by highlighting ridiculous statements and utterances by Ladoja and perhaps creating a conflicting ground for the intending elections. These utterances tensed up the political environment. Giving undue prominence to them could only aggravate the already tense political environment.

\section{Newspaper}

Daily Trust - Normally, antagonists in conflicts have certain misperceptions about each other. Coming out with a publication which sought to minor Ladoja was not the right thing to be done. Daily Trust published stories like the below taking sides with Adedibu and blaming Ladoja blatantly for his woes. But instead of skillfully dispelling these misperceptions, the reportage aggravated the situation. Most of the publications were not liberal at all. Evidences on this position include:

Oyo crisis: When adedibu laughed last: ....the romance between Adedibu and Ladoja did not last.... Prior to this bad blood between the governor and his estranged political godfather, not a few in Ibadan believed that the former rode to office on the back of Adedibu, 
popularly referred to as the Alaafin of Molete by the Who's who in Ibadan politics. Adedibu had also claimed that he single handedly made it possible for Ladoja to become governor of the state at the expense of other top Ibadan indigenes... The governor did not heed the advice and on Thursday, the members of G18 concluded the impeachment process by pronouncing him impeached. His deputy, Otunba Christopher Alao-Akala was immediately sworn in as governor......(January 17, 2006, pg 35)

The story above sought to mock Ladoja and further turn their backs to each other because; Akala also a political godson of Adedibu was inaugurated as the governor when Ladoja was impeached. The story boosted the ego of Adedibu giving a feeling that nobody can get into power in the state without Adedibu's blessings. This reportage caused rancours in Oyo State and the issue was taken to the court and to protest Ladoja's removal, the residents of the State lived in panic as reported thus

Oyo crisis: Ladoja remains governor-court: .....Meanwhile, fear continues to reign supreme in the city as residents of the embattled state continue to stay indoors following increased opposition to the new administration in the state.Unsure of the next political development following the removal of governor Ladoja by loyalists of Alhaji Lamidi Adedibu, most workers have refused to resume work at the state secretariat..... (January 19, 2006, front page)

In order to protest the impeachment of the governor, Wole Soyinka decided to lead a mass rally. This generated counter attack by the Adedibu's faction [12]. The scenario is as captured:

Oyo crisis: Soyinka leads mass rally today: Opposition to the new administration heightened at the weekend with the arrival in Ibadan of human rights activists and pro-democracy forces. The task is to hold a mass rally in the city today to protest the impeachment of the former governor, Rasheed Ladoja. Tagged operation 'flush out the new governor, Otunba Adebayo Alao-Akala and his political godfather, Alhaji Lamidi Adedibu' the rally is coordinated by civil society advocates......and constitutionalism in the state will from now, coordinate protest actions against the shameless and brazen conspiracy of Adedibu/Alao-Akala gangsters against the people's mandate an dwell in the state.....(January 23, 2006, pg 4)

As expected, the Pro-Adedibu faction did not find such threat funny and put up hands-on measure to ensure the futility of the rally after been informed by the newspaper, the conflict was reported thus:

Ladoja: Thugs break up soyinka's rally: Hundreds of people believed to be political thugs, yesterday broke up a massive rally scheduled by Professor Wole Soyinka to protest the unconstitutional removal of former Oyo State governor Rasheed Ladoja, two weeks ago..... However, the protesters were attacked by hundreds by hundreds of machete-wielding thugs who arrived the venue in commuter buses. They were suspected to be supporters of a powerful Ibadan politician. The thugs on arrival, fired gun shots sporadically into the air and threw bottles as the attacked the protesters, injuring some of them in the process.... (January 24, 2006 front $p g$ )

The use of violence- laden language did not help matters and without any confirmation, the paper reported that the thugs were suspected to be supporters of Adedibu even though Adedibu was disguised in some way. It was probably written to create a subconscious feeling that the only person Ladoja had a conflict with was Adedibu and he was likely to have sent the thugs to break up Soyinka's rally. This is further trading blames rather than concentrating on what will de-escalate the already bad conflict that has turned into a calamitous crisis with attendant loss of lives and destruction of property. Stories like the below give evidence to this:

Oyo's unending troubles: The seeming political crisis rocking Oyo State seems to be worsening by the day as ground for another bout appeared to have been set. There are indications that the state, noted for its political volatility, may boil over again and the existing fragile peace shattered following the ongoing attempt by the state government.... (April 4, 2007, pg 8)

Democracy in Nigeria: Godfathers, gun and graft: It's cash handout time at the house of Nigerian Politician Lamidi Adedibu and the car park outside is packed with people eager to get their share. When Adedibu emerges, the men prostrate themselves, the women kneel..... the elderly Adedibu, who will play a decisive role in this month's elections in his South-Western state of Oyo, is flanked by assistants holding plastic bags full of cash...in the last elections, Adedibu sponsored Rashidi Ladoja, who became governor of Oyo State. But the two men fell out shortly after Ladoja took office........... (April 7, 2007,pg 44)

This particular report was culled from Reuters and published by Daily Trust and this gave undue attention to Adedibu's uncouth political style. Since the story was published by Reuters, there was no need to repeat the same report in that newspaper. This forms part of insensitivity to the conflict and definitely escalatory in nature by lauding the person of Adedibu as a political godfather.

\section{Newspaper}

Nigerian Tribune - Even though the conflict between the two parties had already escalated, the Tribune should not have stimulated the appetite of the public for the conflict and set agenda for public discourse as depicted below:

The battle line is drawn: The much-anticipated conflict between strongman of Ibadan politics, Alhaji Lamidi Adedibu and the Oyo State governor, Alhaji Rasheed Ladoja has started manifesting. A classified security report in the possession of Oyo State government said, "There has emerged an anti-government group holding subversive meetings and having the Molete warlord as their leader.... (September 13, 2003, pg. 2.)

With this reportage, the newspaper might have created create panic and a feeling of insecurity generally in the state as the previously minor disagreements between the two parties gave an inkling into what might be expected. The newspaper should not have drawn a battle line for them. This is not solution-oriented but escalatory in nature. Consequently, the conflict perhaps deteriorated into the hurling of heavy abuses by the conflicting parties. Nigerian Tribune did not help matters by featuring the war of words between the two in different stories like the below:

I'm ready for war with ladoja---adedibu: As the feud between the People's Democratic Party (PDP) leaders in Oyo State and the state governor, Senator Rashidi Ladoja rages on, the strongman of Ibadan politics, Alhaji Lamidi Adedibu, has declared that the battle line was drawn between him and the governor.

In the story, the newspaper featured the complaints of the conflicting sides by publishing the violence, vengeful verbal exchange between the two individuals. Still in the same story, Adedibu's is captured: 
He thinks he has become, but he has not become anything.....God is not happy. Who is Rashidi? It will not be well with him.

Replying to this outburst, in the same story, ladoja's aide retorted: He wants to nominate all the commissioners. He also wanted us to handover the treasury to him. This state is too big, too enlightened to hand over to one man. In the last few months, the governor has given this man over N100 millions of his personal money for various purposes. Is he the only man around? (September 22, 2003. Frnt pg)

This is definitely escalatory in nature. This shows negligence and flippancy on the part of Nigerian Tribune as the language used to convey such abusive words could have created panic among members of the State and even the factions loyal to the conflicting sides thereby aggravating the conflict to an extent where the conflicting sides and those in support of them trade blames and engage in verbal exchanges through the newspaper.Also, straight news stories and opinions that tended to put the conflicting parties on unequal pedestals were published to further escalate the conflict. Some examples are below:

Ladoja floors adedibu: Governor Rasheed Ladoja of Oyo State on Saturday confirmed his hold on the party as his candidates defeated those of Alhaji Lamidi Adedibu... (November 30,2003, front pg)

Ladoja, adedibu in battle royale: The festering crisis in the Oyo State chapter of the People's Democratic Party (PDP) between Governor Rasheed Ladoja and his estranged godfather, Alhaji Lamidi Adedibu, on Tuesday assumed a dangerous dimension as thugs, armed to the teeth, invaded the home of the State's Commissioner for Women Affairs, Princess Biodun Babalola...(24 March, 2004, Pg 13.)

Adedibu, ladoja renew hostilities: The hope that the strongman of Ibadan politics, Alhaji Lamidi Adedibu and the governor of Oyo State, Senator Rashidi Ladoja may soon bury the hatchets and settle their differences was again confirmed unrealistic last Thursday as the duo publicly snubbed each other at an event... (April-17, 2004)

2007: No second term for ladoja, adedibu insists: An Ibadan-based politician and chieftain of the People's Democratic Party (PDP), Alhaji Lamidi Adedibu, has maintained that a 100 per cent performance by the governor of Oyo State, Senator Rashidi Ladoja, will not earn him a second term in office...(August -25, 2005, Inside page)

I will only reconcile with adedibu if....ladoja: Oyo State governor, Senator Rashidi Ladoja, has given conditions for which he would be willing to reconcile with his estranged political godfather, Alhaji Lamidi Adedibu. According to Senator Ladoja, any reconciliation that was not based on the interests of the generality of the people would not be welcomed...(September 8,2005, Inside page)

Ladoja held hostage: Hell was almost let loose in Ibadan on Friday night as Governor Rashidi Ladoja was held hostage at the residence of Alhaji Lamidi Adedibu in Molete. Trouble started shortly after the peace meeting brokered between Ladoja and Adedibu has ended at the residence of Alhaji Arisekola Alao and the two advised to return to the Molete residence of Adedibu to cement the new found love... (December 18, 2005, front $\mathrm{pg}$ )

Governor ladoja's last dance: Senator Rashidi Ladoja, is definitely not schooled in the art of war. He does not understand the rules of engagement. Therefore, he does not know when to launch an attack or to retreat. He clearly does not know when to surrender. It is also very certain that the governor of Oyo state is apparently not a student of drama, as such rules of dramaturgy are lost to him. He does not understand those grand norms that condition the rise and fall of a hero... (March 22, 2007, pg 7)

All these sought to de-emphasize peace and enhance the battle for supremacy between the duo. The "Ladoja floors Adedibu" story was obviously not a thing that should have been overblown by the media. The headline had a suggestive tone that could have been misconstrued by anybody that Ladoja and Adedibu were engaged in a physical combat and Ladoja had the upper hand. This definitely is not responsible and peace journalism and is capable of instigating a party against the other. Also the reportage of the second story above depicts a helpless situation that assumed a more dangerous dimension with the invasion of the house of a supporter of Ladoja. Even on issues of little importance, the newspaper served to bring out conflict in every story. That the parties snubbed each other at an event should not have been reported for the sake of peace but it was arranged to further drive solution away from the conflict, leaving no room for reconciliatory moves that would mellow the burning issue down. Also, the issue of Ladoja been held hostage in Adedibu's residence might have meant they were having secret meetings to cement their relationship but as against the peace rule, the paper published that Ladoja was held hostage thereby creating a feeling of insecurity and seeing the conflict between the two as irredeemable. The last excerpt was from an opinion article aimed at just destroying the person of Ladoja. The newspaper allowed the emotions attached to the issue to depict a one-sided reportage in favour of Adedibu.

\section{Newspaper}

\section{The Guardian}

Most stories in the Guardian were on the front pages. They were inciting statements that probably would have served to escalate the conflict. Below is a story that was published after the Supreme Court ruled that Ladoja be reinstated as governor:

Ladoja: 'End has come to jungle justice': Governor Rashidi Adewolu Ladoja Oyo State was effusive in in his praise for the Supreme Court for restoring his electoral mandate, which was snatched from him in controversial circumstances on January 12, this year.......(December 8 , 2006, front page)

This story covertly referred to Adedibu and the language used suggests that Ladoja was pushed out of office by Adedibu and underneath the same story, Adedibu's position on the issue found expression in the following story.

"Don't come to oyo", adedibu, alao-akala warn Ladoja: Although he has secured victory at the nation's highest judicial chamber, Oyo State Governor Rashidi Adewolu Ladoja may have to contend with a determined opposition at home. His tormentor-in-chief, Alhaji Lamidi Ariyibi Adedibu, yesterday vowed that the judgment notwithstanding, Ladoja would not return to the office as governor.....At the Molete home of Adedibu, everywhere was calm. His supporters stood in groups to discuss the development, while the PDP chieftain sat amidst his loyalists.Adedibu in a chat with The Guardian said that the apex court judgment could not help Ladoja in any way......(December 8,2006 , front page)

Seemingly unhappy with the development, the paper celebrated and conveyed the orders of Adedibu to Ladoja, creating a feeling that crisis was in the offing based on the reinstatement. The paper did a lot of editorializing by stating that Adedibu was Ladoja's tormentor-in chief. Such name-calling is capable of escalating the situation. In addition to 
giving a panicky feeling that the battle had just begun between the conflicting sides, the story gave a hint on the expected turn of events which must have played a decisive role in determining the new trend in the conflict. However, to counter the report, the paper published that Ladoja would resume the next day with assurance from the Inspector General of Police.

Ladoja resumes noon tomorrow: After days of uncertainty that surrounds his reinstatement courtesy of a Supreme Court judgment last week, the coast seems clear for returnee Governor of Oyo State......The cheering news came yesterday through the Inspector General of Police....(December 10, 2006 front $\mathrm{pg}$ ).

....Adedibu camp in disarray: The political camp of the strongman of Ibadan politics, Chief Lamidi Adedibu was in disarray yesterday when the news broke that the reinstated governor Rashidi Ladoja would resume work latest 12:00 noon on Monday...... There was wild jubilation in Ibadan when the news of Ladoja's coming was received. Many people trooped out to sing praises that truth at last prevailed over falsehood.... The situation was further worsened for the Adedibu camp as last minute effort to seek the intervention of President Olusegun Obasanjo to save Akala was rebuffed.... (December 10,2006 front pg).

This was inciting because there was nothing to classify the news as "cheering". The story is not balanced as The Guardian did not leave the conclusion to the readers while conveying its point of view; it is obvious that emotions were attached to the story. The stories were perhaps written to create tension and an atmosphere of ill-feeling and bitterness. The conflict assumed alarming dimensions that made the factions to prepare to unleash mayhem in case Ladoja resumed as governor and it found expression in this story:

Crisis looms in oyo over ladoja's return: The anti-Rashidi Adewolu Ladoja camp in Oyo State is clawing at any strand to remain in office, despite a Supreme Court judgment against them and President Olusegun Obasanjo anti-'s directive that the verdict must be enforced. This morning, the camp hopes to 'arrest' the judgment of the apex court..................Also it was learnt that members of the opposition camp have printed vests and camps bearing the inscription: 'Welcome Ladoja' which suspected thugs would wear to unleash mayhem of residents troop out to welcome the Governor when he arrives in Ibadan today... (December 11, 2006, front pg)

These reports which seem harmless must have escalated the issue as it set the pace for how the day was going to look like. This is a conflict inflaming report that set the pace for the mayhem that was unleashed when Ladoja reclaimed office as governor by featuring reactions from both parties with Adedibu's faction threatening fire and brimstone and finally reporting the new, dangerous and alarming dimension the conflict has taken.

Ladoja reclaims office as oyo governor: It was a triumphant entry for Governor Rashidi Adewolu Ladoja of Oyo State yesterday as he reclaimed the mandate that was forcibly taken from him by a faction of the State House of Assembly on January 12 this year. (December 12, 2006, front page)

Hoodlums unleash mayhem...adedibu flown to Abuja: As feared, the determined opposition to return of controversially impeached Oyo State governor Rashidi turned bloody yesterday. One person was feared dead while many others were macheted by hoodlums believed to have been hired by a frontline politician in the state. Also yesterday, Oyo State political kingpin, Alhaji Lamidi Adedibu, was sighted at the domestic wing of Murtala Mohammed airport in company of heavily armed security operatives..... The violence which was directed at the perceived supporters of Ladoja, who has gathered in group to receive the reinstated governor at different locations in the city, caused a delay in the resumption of the governor scheduled for $2 \mathrm{pm}$.... The political thugs arrived at the vicinity of the secretariat at about $12: 25 \mathrm{pm}$ in buses armed with dangerous weapons including cutlasses, axes and guns. They descended on the supporters of Ladoja....However, Adedibu wearing a cream Dansiki attire, arrived at the airport at about 5;30 pm and was quickly taken to the departure hall......(December 12, 2006, front page)

Policemen, anti-ladoja lawmakers seize Oyo assembly: For the second time in one week, Ibadan, the Oyo State Capital was yesterday in the vice grip of hoodlums. Both the policemen and the hoodlums gave protection to the 18 lawmakers of the state House of Assembly whose impeachment of the governor, Alhaji Rashidi Adewolu Ladoja, has been voided by the courts. The lawmakers swooped on the Assembly premises to stop their victorious colleagues from gaining entry into the chamber. The convoy of vehicles in which they stormed the complex included a sports utility van (SUV) belonging to Alhaji Lamidi Adedibu, a controversial politician and arch-enemy to Governor Ladoja......

The Guardian learnt that the group of 14 lawmakers loyal to Ladoja had planned to resume sitting yesterday. Already, the pro-Adedibu lawmakers were said to have gone away with the mace to prevent the pro-Ladoja lawmakers from resuming work... (December 15, 2006, front pg)

The use of vicious-laden language to explain the conflict did much to escalate the conflict and the fact that the conflict which has aggravated to become a state crisis made it all the more dangerous. So unfortunate was that the conflict did not subside, rather it escalated the more without proposals for resolution such that the anti-Ladoja faction of the lawmakers took the conflict to the peak with the other faction at the House of Assembly

\section{Newspaper}

\section{The Punch}

2007: Adedibu can't stop me- Ladoja: Oyo State Governor, Alhaji Rashidi Ladoja, has said that the acclaimed strongman of Ibadan politics, Alhaji Lamidi Adedibu, will not be a stumbling block to his ambition if he seeks a second term mandate...(March 9, 2005, Inside Page)

On his ambition for the 2007 elections, Ladoja opinion found expression in the above story saying that Adedibu would not be a stumbling block in his ambition. This had some conflict fuelling undertone and even more spiteful condemnations found its way into the paper by way of Ladoja's complaints as a matter of the love lost between the conflicting parties. Rather than propagate the hate contents, the stories should have had reconciliatory undertones rather than conflict- stimulating sensations from a party in the conflict against the other. Examples are below:

Party crisis: Ladoja takes on adedibu: Oyo State Governor, Alhaji Rasheed Ladoja, on Monday debunked the statement credited to his political mentor, Alhaji Lamidi Adedibu, that he was the landlord of politics in the state, stating that he was not as powerful as it was being perceived in certain quarters. 
Ladoja, told newsmen in Abuja after meeting, behind closed doors, with President Olusegun Obasanjo and Vice-President Atiku Abubakar that Adedibu had no moral justification to describe himself as the leader of the ruling People's Democratic Party in the state as he was a latecomer to the party after defecting from the All Nigeria Peoples Party. The governor said: "Who is the landlord? Is it the person that got there first? Or how do you define the landlord? ....... (27 July, 2004, Inside Page).

I don't owe my election to adedibu- Ladoja: Oyo State Governor, Alhaji Rashidi Ladoja, on Saturday insisted that he did not owe his election as governor to his estranged godfather, Alhaji Lamidi Adedibu. Ladoja told journalists in Ibadan at a forum to mark the second anniversary of his administration that the claim by Adedibu that he enthroned the governor was a political gimmick which lacked relevance. He said Adedibu's numerous apologies to the electorate for 'misleading' them to vote for him in the 2003 elections would not make him abandon the mandate entrusted in him by the people to satisfy the interest of one man.(30 May, 2005, Inside Page)

Ladoja's march to victory: The acclaimed godfather of Ibadan politics himself, Alhaji Adedibu who was on hand to witness the proceedings did not also disappoint that day..... the way two Senior Advocates of Nigeria.........marshaled their arguments left the audience inside the court no doubt that except the proverbial Nigerian factor was revisited, victory was sure for Ladoja. Inside the court room, Adedibu and his horde of aides that accompanied him to the courtroom shifted from their seats uncomfortably each time Olanipekun and Ali put up what was considered brilliant arguments.... (November 5, 2006, pg 45)

This reportage by Punch displayed outright partisanship, bias and preference for Ladoja over Adedibu. The generalized atmosphere created here negates the principle of balance and fairness. Balance and neutrality are key concepts in reporting conflicts but these have been neglected in the reportage of the conflict. The Punch failed to use its agenda-setting power to direct the attention of the general public to other salient issues that could have brought about the de-escalation of the conflict. Attention was only focused on the events rather than the issues.

EFCC probe: my opponents are confused: The Government of Oyo State, Alhaji Rashidi Ladoja, on Saturday said that the political camp of his opponents had become unsettled since the Chairman of the Economic and Financial Crimes Commission......

However, the controversy that aroused one of the greatest passions in the newspaper was the House of Representatives bye-elections on which the conflicting sides clashed. There were records of many inciting and reckless statements attributed to the conflicting sides. The influence of these was suspected to have increased the scope of the conflict.

Reps by-election: ladoja, adedibu feud deepens: The feud between the former governor Oyo State, Senator Rashidi Ladoja, and a chieftain of the People's Democratic Party, Chief Lamidi Adedibu, over the proposed January 26 House of Representatives by-election in Oyo State has deepened with the nomination of candidates for the poll. (January 5, 2008, pg 10).

The conflict did not subside but deepen such that the conflicting parties differed on their nomination of candidates for the election but ordinarily, one would have expected them to nominate their candidates but reporting this as something that has deepened the conflict would definitely aggravate the conflict.

\section{Discussion of Findings}

\section{Research question 1}

To what extent did the reportage tend to escalate and de-escalate the conflicts within the period under study?

There was a strong and indisputable relationship between the reportage of the conflicts by the newspapers and the escalation of the conflicts to violence, civil disorder and destruction of lives and properties. Ever before the beginning of the conflict, there had been massive demonization of Adedibu and ladoja as influential political godfather and godson respectively in the newspapers .In a way, the psychological and emotional dispositions of the public had already been influenced by the images of "he" "him" "them" conjured in the newspapers as a result of power struggle and political machinations that heralded the return to civil rule in Nigeria on May 29, 1999. The lauded political godfather and godson were able to garner and win supporters and loyalists who did not help matters in political conflicts that ensued between the godfather and godson later. This pool of supporters readily provided adequate foot soldiers that participated in the subsequent conflict between the two parties. When examined from the perspective of the influence the mass media have on the attitude and perception of their audience [13-14], the undue emphasis on political formidability of politicians by the newspapers certainly provided an attitudinal and behavioural structure within which the public could have reacted in the conflict and the violence that accompanied it. The newspapers devoted very little and insignificant attention to any resolution of the conflict. They even predicted the violence and the attendant cataclysmic consequences of the conflicts, thus setting negative agenda for the public. The manner in which the newspapers reported the conflicting parties and their utterances was conflict-provocative and at best inciting because of the rivalry image conveyed through the newspapers' contents to the public. Many of the analyzed latent and manifest contents confirm the strong relationship between the contents of the selected newspapers and public violence that accompanied the conflicts. The papers seemed to have reported from the prism of the conflicting parties they supported, and so no effort at all was made to verify some of the stories that the newspapers published just because such stories were perceived to favour the conflicting party the newspapers supported. It is also evident in the data provided that, none of the newspapers, for example, ever reported that the conflicting party it supported engaged thugs and unleashed violence, as were the cases during the conflicting periods. To the papers, it was only the conflicting party that they did not support that engaged in such misdeeds while the conflicting party they supported and his loyalists were often victims. This, no doubt, contributed to the escalation of physical conflicts and violence that ensued between the conflicting parties during the period of study.

\section{Research question 2}

To what extent did ownership of the selected newspapers affect the reportage of the conflict?

Ownership influence greatly affected the reportage of the personality-induced political conflicts by the selected newspapers during the period of study. The newspapers, in their own capacities, served as shadow parties to the conflicts and this had pervasive 
influence on their contents and reportorial directions. This accounted for the reason why in some of the coverage and contents of the newspapers analyzed, partisan political considerations were given priority over the social responsibility roles of the newspapers. It was speculated that why Obasanjo supported Adedibu against Ladoja was because ladoja had sympathy for Abubakar and did not support Obasanjo then in his botched third term bid. When, Ladoja was eventually impeached in 2006, he sought refuge and asylum with the then Governor of Lagos State, Ahmed Bola Tinubu, who was speculated to have sought and won the allegiance of the Punch newspaper. Consequently, ACN became a shadow party in these two conflicts and Punch was seemingly used in drumming support for Ladoja against Adedibu.. As shown in the evidences provided in the analysis of the latent and manifest contents of the sampled editions of the newspaper, most of the stories carried by the newspaper were favourable to Ladoja. Suppose it was certain whether profit making and economic reason was part of the motivations the newspapers had in reporting the conflicts during the period under study, there would have been more definite findings and positions on the relationship between ownership of the newspapers and the reportage of the conflicts. This is beyond the scope of this study.

\section{Research question 3}

How socially responsible was the coverage of the conflict by the selected newspapers?

The newspapers reported the conflicts in socially-irresponsible manner. The reportage reflected incitement, partisanship and bias on the part of the newspapers. Such reportage could not have helped in reconciling the conflicting parties, but fuelled the conflicts to violence and public unrest. The reckless mode of reporting the conflicts by most of the newspapers affiliated to conflicting parties during the period of study prevented the newspapers from giving thought to how the conflicts could be resolved and how the violent acts and destruction of lives and property that accompanied the conflicts could be forestalled. The newspapers incited the conflicting parties against each other. In some instances, the newspapers were even justifying violence as a way of teaching the incorrigible political godfather and godson the lessons of their life, especially when such violence was planned by the supporters of the conflicting party that had the sympathy of the newspapers. In addition to this, the inciting contents of the newspapers could have contributed to the aggravation of violence. In instances where the newspapers rationalized the use of violence to achieve political goals, the reading public was made oblivious of the consequences of such violence. Since newspapers were encouraging it, violence was seen as a rational way to attempt to attain political goals by a largely illiterate population. In essence, the irresponsible reporting and reckless activities of the newspapers contributed in no small measure to aggravating the violence that accompanied the conflict. Consequently, the reportage of the conflict by the selected newspapers was largely socially irresponsible.

This study was carried out to investigate newspaper reportage of political godfather-son conflict between Governor Rasheed ladoja and Chief Lamidi Adedibu in Oyo state, South-Western Nigeria, between 2004 and 2006. In this study, Nigerian press was observed to have made substantial contributions to the political conflict that the study investigated how selected newspapers reported. The study explored the contents of the selected newspapers with a view to ascertaining the extent of these contributions. The study adopted a qualitative approach in the data collection process. Principally, the study adopted the dialectical hermeneutics style of textual analysis. Both the manifest and latent contents of the sampled editions of the selected newspapers were subjected to analysis with a view to investigating how partisan, neutral and socially responsible were the newspapers in reporting the conflict and the violence that accompanied it. Thus, analysis of the contents of sampled editions of five nationally-circulated newspapers was carried out to obtain data that assisted in providing adequate insights into the nature of the reportage of the conflict by the selected newspapers during the study period. The newspapers whose contents were analysed included Daily Champion, Daily Trust, Nigerian Tribune, The Guardian and The Punch. The contents of the newspapers were analyzed as they manifested qualitatively within the hermeneutical framework of textual analysis.

It was discovered that all the selected newspapers deployed absolute majority and overwhelming percentage of their coverage to reportage that tended to escalate the conflicts rather than de-escalate it. The escalatory stories showed incitement, partisanship, bias and social irresponsibility on the part of the newspapers. These contents could not have helped mitigate between each pair of the conflicting parties, but rather, fuelled the conflict to a situation of violence and political unrest. Although, this finding reinforces the sacrosanct nature of 'conflict' as a news determinant, but leaves much to be desired in respect of the role the media are expected to play in reporting conflict. Consequently, the newspapers reported the conflict in sociallyirresponsible manner. The reckless mode of reporting the conflict by most of the newspapers affiliated to conflicting parties during the period of study prevented the newspapers from giving thought to how the conflict could be resolved and how the violent acts and destruction of lives and property that accompanied the conflict could be forestalled. The vast reportage of the conflict by the newspapers was largely negative and socially irresponsible and this trend has become another constraint to the development of democracy in Nigeria.

\section{References}

1. Peterson S, Schramm (1956) Four Theories of the Press. University of Illinois Press.

2. McQuail D (1987) Mass Communication Theory: An Introduction, London: SAGE Publications.

3. McQuail D (2000) Mass Communication Theory 4th ed., London: SAGE Publications.

4. McQuail D (2005) Mc Quail's Mass Communication Theory 5th edn. London: SAGE Publications.

5. Joseph R. (1999) Democracy and Prebendal Politics Nigeria: The Rise and Fall of The Second Republic.

6. Adeoye A (2005) Godfatherism and the Future of Nigerian Democracy. African Sociological Review 9: 79-105.

7. Okoye I (2007) Political Godfatherism, Electoral Politics and Governance in Nigeria. Presented at the 65th Annual Conference of the Mpsa Held In Chicago, USA.

8. Olarinmoye O (2008) Godfathers, Political Parties and Electoral Corruption in Nigeria. African Journal of Political Science and International Relations 2: 66-73.

9. Dare B (2003) House of War: the story of Awo's followers and collapse of Nigeria's second republic. Ibadan: Spectrum books and Tell Communication.

10. Owens-Ibie N (2002) Socio-cultural Considerations in Conflict Reporting in Nigeria. In Introduction to Conflict Reporting in Nigeria, Lagos: Friedrich Ebert Stiftung.

11. Lasswell HD (1948) The Structure and Functions of Communication in Society, in Bryson (ed.) The Communication of Ideas, New York: Holt Rinehart and Winston. 
Citation: Popoola M (2014) Political Godfather-Son Conflict in South-Western Nigeria, 2004-2006: The Role of the Press. J Mass Communicat Journalism 4: 205. doi:10.412/2165-7912.1000205

Page 11 of 11

12. Shaw M (1996) Civil Society and Media in Global Crises: Representing Distance Violence, London: Printer Publishers.

13. Ginner-Sorolla, Chalken (1994) The Causes of Hostile Media Judgements. Journal of Experimental Psychology 30: 165-80.
14. Wimmer RD, Dominick J (1987) Mass Media Research: An Introduction, California: Wadsworth. 